\title{
VALUE INVESTING - ESSENCE AND WAYS OF FINDING UNDERVALUED ASSETS Elitsa PETROVA
}

\author{
"Vasil Levski” National Military University, Veliko Tarnovo, Bulgaria \\ elitsasd@abv.bg
}

\begin{abstract}
Efficient market hypothesis considers that because many talented analysts constantly searching the market for the deals in a short period, after a certain point of time there are not so attractive deals. According to the hypothesis, successful investors owe their success more to luck than to their skills. The paper presents the Value investing. Value investing is an investment paradigm, which stems from the ideas of Benjamin Graham and David Dodd. The proponents, including the chairperson of Berkshire Hathaway Warren Buffett, argue that the essence of value investing is to buy shares at a price lower than their true value. The difference between the market price and intrinsic value of the stock Graham called the "margin of safety".
\end{abstract}

\section{Keywords: investment, value investing, undervalued assets}

\section{Introduction}

Efficient market hypothesis considers that because many talented analysts constantly searching the market for the deals in a short period, after a certain point of time there are not so attractive deals. According to the hypothesis, successful investors owe their success more to luck than to their skills. Benjamin Graham, described as the father of modern investment analysis considers that finding a bargain is difficult and even impossible in today competitive environment.

Active investment (active investing), also called active management of a portfolio of financial assets is a strategy for making investments in order to surpass the benchmark index. Investors and mutual funds that do not seek to transcend benchmark index often invest in index funds that seek to adhere to this index. [1] Passive investment (passive investing), also called passive management is a financial strategy, whose main idea is to minimize and avoid the adverse consequences of lack of proper prediction of the future. Through passive investment is maintained a welldiversified portfolio of major types of securities, without attempting to achieve better results than other investors with finding securities with variation in price.

\section{Essence of value investing}

The development of stock markets and the system of investment information, as well as increasing the volume of knowledge of individual investors creates new forms and strategies for attracting and using free savings. [2]

Value investing is an investment paradigm, which stems from the ideas of Benjamin Graham and David Dodd. [3] The proponents, including the chairperson of Berkshire Hathaway Warren Buffett, argue that the essence of value investing is to buy shares at a price lower than their true value. 
The difference between the market price and intrinsic value of the stock Graham called the "margin of safety".

Investors often look for ways to beat the market. Investing in value shows how to beat the average annual return of the S\&P 500. Each buyer knows that if he waits for the right moment he can get any product at a lower price than the original on which the product has been proposed. This idea could be applied to investments.

If we know the true value of something it can be purchased only when it is in a sale. Whether buying a new appliance when it is in sale or sold in its full price, we get an appliance with the same characteristics. Similarly the share price of the company can be changed, even if the true value of the company is maintained. The share is a commodity and as each commodity go through periods of higher and lower demand. These fluctuations change their prices. No sense to pay full price for the appliance, as it may be to sell a few times a year. It is the same with securities. The only difference is that we cannot predict the sale of shares nor their selling prices will be advertised widely.

Buying securities at bargain prices gives a better chance at receiving income later in their sale. Furthermore, the loss is less if their prices did not increase as investor hopes. This principle, called the margin of safety is one of the key success factors of value investing. [4] It has sometimes application in shopping. When we buy new clothes, we can be reluctant to pay their full price, because sometimes a garment does not appear good enough. It may look good, but after some time its colors fade or it shrinks. If you buy a dress on sale for $\$ 30$ instead of paying its full price of $\$ 80$, you will only lose $\$ 30$ on the purchase of not good enough dress, but if you pay its full price, you will lose significantly larger.

Investors in value just apply this reasoning. If a share costs $\$ 100$ and an investor buy it for $\$ 70$, he will make a profit of $\$ 30$ and should wait for rising of share price to its actual value of $\$ 100$. Moreover, the company can be expanded, allowing the accumulation of additional benefits. If the share price rise till $\$ 110$ it will be realized gain of $\$ 40$, only because of the purchasing it on sale. However, if we bought it at its full price of $\$ 100$, would be realized only $\$$ 10 profit. Benjamin Graham, advises investors to buy shares when the price is two-thirds or less than their real value. [5] Value investors do not believe in the efficient market hypothesis. They believe that sometimes the shares are undervalued or overvalued. A share can be underestimated if the economy is performing poorly and investors are in panic, or may be overvalued as investors have become too excited about the new technology that has not yet proven.

Investors in value do not follow others. When all investors buy, they often sell. When all investors sell, they buy or already own the stock. They do not buy the most popular shares of the day, because they usually are the most expensive, and invest in companies that are not known, or even those who are in difficulty if their financial indicators are reliable.

Value investing is a long-term strategy - it does not provide instant gratification. Value investors do not expect to buy one share for \$ 66 on Tuesday, and to sell it for \$ 100 on Friday. In fact, they may have to wait years before the stock investment to pay off. When you have savings to invest in shares, you will not want to buy a stock just because it represents a share of ownership in your favorite company - you will want to buy this one, which is at the most attractive price. In addition, if the price is not satisfactory, you cannot buy anything.

\section{Finding undervalued stocks}

There are various reasons why the shares can be traded under their real value. People often invest irrationally. They buy when the price of a share increases and do not want to miss the profits that others have already achieved. Similarly, when the price of a share is reduced or when the value of the 
overall market falls, most people sell their shares. They do not want to lose everything and fear of uncertainty. So rather, than wait for the market to move in a good direction for them, they take the loss.

In 2000, technology stocks and housing bubble was fueled by dramatic levels of overinvestment, so the prices of technology stocks and real estate were overvalued. When the market began to collapse, investors panicked causing a situation where some shares began to be assessed closer to their real values, while others even fall under their real values.

Investing is not always something exciting. Everyone wants to make a fortune by investing in something exciting as buying shares of startup hitherto unknown technology than by buying shares of established manufacturer of durable consumer goods. Foreign shares and any other securities, which are not known sometimes, have more potential than it seems to have.

Sometimes even good companies are facing obstacles. However, just because a company experiences financial difficulty, it does not mean that it is not fundamentally valuable or it does not recover its capacity. Companies with real value may experience a significant decline in its shares' price, and investors often overreact to information and are willing to sell the shares of these companies. Those investors who consider the long-term value of the company can turn the setback into opportunities for profit.

Sometimes a company has unprofitable divisions that drag down its performance. If the company sells or terminate their activities, its financial performance can improve. Value investors who see this potential can buy shares until their price is into economic depression and see future profits.

It is a general trend for companies to go through periods of higher and lower profits. Economy reflects the mood of consumers and makes them buy more or less.
Consumer behavior can affect the share price, which has nothing to do with longterm value of the company.

For these and other reasons, the share prices can fall, although the company continues to create value for its shareholders and customers.

\section{Finding value in the financial statements and balance sheets}

The necessary information about the financial position of the company can be found easily and quickly via the Internet. Major financial sites (including Investopedia.com) enable investors to obtain information such as share price, shares outstanding, earnings per share and news about the industry. Some sites filtered data for the shares in accordance with predefined criteria, such as shares in certain proportions. For some calculations, we can use already established mechanisms. Yahoo provides data on the current position of the companies and many important financial indicators in the category called "Key Statistics".

Examples: (BBRY)

Key statistics of BlackBerry Limited

$\mathrm{http}: / /$ finance.yahoo.com $/ \mathrm{q} / \mathrm{ks}$ ?s=BBR $\mathrm{Y}+$ Key+Statistics

Key statistics of Yahoo! Inc. (YHOO)

$\mathrm{https}$ ://finance.yahoo.com/q/ks?s=YH $\mathrm{OO}+\mathrm{Key}+$ Statistics

The financial statements are annual and quarterly results of the performance of a company. US companies are required to file such reports by the Securities and Exchange Commission (SEC). We can find them on the website of the SEC or the Investor Relations website.

Important ratio that investors want to calculate using data balance is current liquidity, which compares total current assets of the company with total current liabilities. The ratio shows how easily a company can cover its current liabilities and disclose the total liquidity position of the company. As higher it is, such better, but value investors want to see the current ratio 
of at least 2-1, which means that the company has at least two times more assets than current liabilities.

Investors are interested in working capital of a company. To get information for the net current assets (working capital), subtract current liabilities from current assets, and divide the result by the number of shares in circulation. In this way we will receive net current assets per share.

Another important indicator is the ratio of debt to assets, which is defined as total liabilities divided by the total assets. Companies whose debt exceeds $50 \%$ of their assets are avoided. As lower is this ratio, such better.

The book value shows the net value of the company - its assets minus liabilities. Book value per share is obtained by dividing the net value of the company to the number of shares in circulation. Value investors are interested in companies when their stock price is under the book value per share. If a company has a net value of $\$ 20$ million and 500,000 shares outstanding, its book value per share is 20 million $\$ / 500,000$, or $\$ 40$. If the shares traded for $\$ 20$, it is recommended to investigate further. Comparing the price of $\$ 20$ with a book value of $\$ 40$ gives us the ratio of price-book value $(\$ 20 / \$ 40=$ $0.5)$.

Looking at the statement of income and expenditure the investor will be informed how much money the company received from the sale of their products and / or services. The increase in sales shows that the company is growing. Subtracting the cost of revenues from actual revenue generates gross profit or realizes how much is revenue after subtracting the cost of producing what the company sells. Subtracting total operating expenses from gross profit is formed the operating income of the company. After deduction of interest expense and income taxes from operating profit it is obtained net income of the company.

The last lines of the statement of revenue and expenditure provide information on the net profit per share. If we divide the amount of revenue to the number of shares in circulation, we will get basic earnings per share. Report also shows how the number of shares in circulation changes over the time. When the number of shares decreased, which is situation of redemption of shares, this activity is good sign that shows the confidence in the future work of the company. This also means that any share of the capital of the company is entitled to a higher rate of profit.

\section{Conclusion}

Although value investing strategy is to invest with risk below average, it can bring certain risks.

- Sometimes it is observed unusually large losses or profits from events such as natural disasters, corporate restructuring and other, which are reported in the statement of income and expenses as an extraordinary item - profit or extraordinary item - loss. In making financial calculations it is important to remove these financial anomalies to obtain a realistic picture of how the company is presented in a simple year.

- According to many scientists, we need to invest in a wide variety of companies and industries. However, a diversified portfolio may exist, even if a small number of shares represent various industries and sectors of the economy in it. Christopher Brown recommends owning at least 10 shares, and Benjamin Graham believes that the holding of shares of 10-30 companies is good enough variety.

- The ideal time to sell a stock is when the shares are overvalued relative to the intrinsic value of the company.

Finally, it should be emphasized that investment management is a global industry, generating billions of revenue. On the investment markets, participants take different investment strategies, which 
generally can be divided to active and passive investment strategies.

Value investors believe that stocks may be overvalued or undervalued, and because of this it is possible to beat the market. Value investing is both active strategies because it includes study and selection of individual stocks and monitoring their performance, but also a passive strategy, because it includes a long investment horizon. In any case, the value investing is a long-term strategy.

\section{References}

[1] Sharpe, William F, The Arithmetic of Active Management, The Financial Analysts' Journal Vol. 47, No. 1, January/February 1991. pp. 7-9 Copyright, 1991, Association for Investment Management and Research Charlottesville, VA, http://www.stanford.edu/ wfsharpe/art/active/active.htm

[2] Nichev, N., The demand for income and investment strategy of the funds, Research Papers 64, VVOVU "Vassil Levski", Veliko Tarnovo, 1998.

[3] Graham, B., Dodd, David L., Security Analysis, New York: McGraw Hill Book Co., 1934.

[4] Graham, B., The Intelligent Investor, New York: Collins, Ch.20, 1949.

[5] Graham, B., The Intelligent Investor, New York: Collins, Ch.20, 1949 